\title{
第15回国際ガラス史学会大会報告
}

\section{A Report on the Meeting of AIHV \\ (Association Internationale pour l'Histoire du Verre), October 2001}

東 容子草

\section{I. 大 会 概 要}

国際ガラス史学会 (AIHV: Association Internationale pour l'Histoire du Verre) の 第15回大会が，2001年10月15日から20日まで，The Metropolitan Museum of Art (以下 MMA と略す) と The Corning Museum of Glass（以下 Corning と略す）を舞台に開 催された。この学会は基本的に 3 年に一度開かれるもので, 今回会場となった二館が引 き受けたのは，ともに古代から現代までのガラスコレクションを有するアメリカの代表 的な館であると同時に, 折り良くイスラムガラスの名品を一同に集めた展覧会 “Glass of the Sultans”を共同で開催している時期だった為であろう。その関連でイスラームガラ スの研究がひとつの大会テーマとなったことは，本大会の特徴であった。

今回テーマとなったイスラームガラスなど, 個別のテーマに関しては, 他の参加者に よる詳細な報告が行われるということで, ここでは, 大会全体の概要とプレ・ローマに 関する研究に関しての報告を行いたい。

この学会は 9 月11日のアメリカ同時多発テロの直後であったため, 大会参加者数は 123 名で予定よりかなり少なく, 研究発表は当初103件が予定されていたが, 実際には71件(内 ポスターセッションが13件）に留まった。参加者は欧米各国が中心で，オーストラリア， イスラエル，日本から数人ずつの参加者があった。この大会に伴ない北アメリカ各所の， 主に近現代がラス作品の見学ツアーも予定されていたが, 残念ながらッアー申込者が定 員に満なないため中止となった。

このように参加者の出足が鈍ったばかりか, 開催そのものも一時は危ぶまれたが, 主 催者側が出席予定者全員にニューヨークの詳細な状況報告と開催の決意を連絡し, 実現 の運びとなった。学会がスタートしてからは全てのプログラムが順調に進み, 主催者の 行き届いた配慮と並々ならぬ努力が感じられた。この危機的状況を乗り切って有意義な

* MIHO MUSEUM 学芸員

Curator, MIHO MUSEUM 
学会の成功を導いた MMA の Stefano Carboni, Lisa Pilosi, Corning の David Whitehouse, Jane Shade Spillman 各氏に，深甚なる謝意を表したい。

\section{II. 大会スケジュール}

10月14日 早めに MMA に到着した参加者のために, Stefano Carboni (メトロポリ夕 ン美術館・イスラム担当学芸員）が “Glass of the Sultans” の公開講座 “From Desert Sand to Glittering: Glass Fit for a Sultans”を案内された。

10月15日 The New Ark Museum と The Cloisters の見学会が行われた。The New Ark Museum では, “Fire and Light 3,000 Years of Glass Artistry”展が開催され，常 設の古代ガラス (Eugene Shaefer コレクション) 及びョーロッパ・アメリカガラスの展 示も楽しむことができた。The Cloisters はニューヨーク市郊外の川のほとり，自然の中 に移築復元された南フランスの修道院で, MMAの中世美術を展する分館であり，ここ で歓迎レセプションが行われた。

10月16日 MMA 館長 Phillipe de Montebello および学会長の Jennifer Price の挨 拶の後，発表が始まった。各自20分の持ち時間で，この日はイスラームガラスに関する 13の研究発表が行われ, 日本から真道洋子氏が “Islamic Glass from al-Raya” と題して 発表を行った。18時からは“Glass of the Sultans”の内覧会とレセプションが行われた。

10月17日 午前中は 7 つのグループに分かれて見学会が行われた。午後からはローマ・ 中世など 4 つの発表が行われ，またポスターセッションには藤井慈子氏が “Iconographical study of the scene 'Baiae' incised on Roman Flasks”のテーマで参加した。

午前中の見学会テーマは,「MMA の古代ガラス」「MMA のヨーロッパガラス」「MMA の近代ガラス」「アメリカンガラス (MMA 館内および St. Michael's church のッアー)」

「ガラスのX線微小分析」「アバンギャルドのガラス：ビエンナセセッションからバウハ ウスまで (Cooper-Hewitt Museum にて)」「ユダヤ美術館のガラス」である。

10月18日 ニューヨークからコーニングヘチャーターバスで移動し, 途中で Dorflinger Museum に立ち寄った。ここは19世紀に設立された Dorflinger ガラス工房の作品を 展示する私設美術館で，美しい湖のほとりにある。夕方 Corning に到着し，歓迎レセプ ションと共にスタジオ見学が行われ, ベネチアンガラス, トンボ玉，カットガラスなど の実演が行われた。

10月19日 Corningの Brill 氏他により，現代インドの伝統的なガラス製作に関して， ビデオ上映の形で基調講演が行われた後，2会場に分かれて発表が行われた。第 1 会場 はプレ・ローマ及びローマガラス, 第 2 会場は中世, イスラーム, 近現代の作品をテー マとする発表であった。夕方から Rakow 賞の受賞作品発表が行われ, ベニス在住の現 
代ガラス作家大平洋一の作品が選ばれた。

10月20日 2 会場に分かれての発表が続いた。第 1 会場はローマ,第 2 会場は17世紀以 降と極東のガラスをテーマとする発表があり, 谷一尚氏が “The six-lobed glass cups of Tang Dyn: recently excavated in China”と題して発表を行った。その後大会の総括, 再びガラス制作デモンストレーション見学があり，大会は幕を閉じた。

\section{III. 研 究 発 表}

今大会で行われた発表を内容的に大きく分類すると，ポスターセッションも含めてプ レ・ローマが 7 件，ローマが 23 件，中世が 6 件，イスラームが 13 件，近現代が 13 件，極東 は 2 件で，時代をまたがるものが 4 件，その他 3 件となっており，発表の対象地域の多 くが地中海・中近東周辺であった。

これを内容的に分類すると，全体を通して考古分析的研究が $22 \%$, 製作技法が $22 \%$, 芸 術文化的研究が $20 \%$, 形状および機能的研究が $15 \%$, 流通や市場に関する研究が $15 \%$, そ の他 $9 \%$ という比率である。

近現代がラスの芸術文化的研究が多かったり，中世は発表件数が少なく考古分析と技 法に偏っていたりするが, 総じていろいろな角度から, 各時代の研究がなされていると 言えよう。

最後に, ローマ以前の古代ガラス研究に関する発表に関しては，内容を一見してみた い。発表数は，ポスターセッションを除く口答発表が 4 件であった。

ひとつは, Birgit Schlick-Norte 氏による前10世紀頃の墓から出たエジプトガラスの 製作法についてである。新王朝時代以降のエジプトにおけるガラス器に関しては，これ まで，ガラス質のファイアンスにおされ，その実体が明らかではなく，エジプト学研究 者によっても着目されてこなかった分野である。彼女によると, 新王朝よりガラス自体 の質は落ちているが，コアとは違う技法が使われていたという画期的な内容であった。

次は Kalliopi Nikita 氏によるミケーネガラスについての発表であった。これまで, 東 地中海諸島部のガラス製造に関しては，ミケーネ文化との関わりで重視されてきた。し かし, 今回，ギリシャ本土におけるガラス製作について，クレタ島，エーゲ海域，キプ ロス島などの製作地と比較しながら，論述された。

続く Pavlos Triantafyllidis 氏は, アケメネスタイプの鋳造ガラスについてであった。 これまで, 金属器との関連は言及されてきたが, この発表では, 最近の発掘資料を網羅 して器形および製作年代による分類を行い，製作地と地中海・オリエント世界全域に及 ぶ交易の可能性を推測した。

最後は, Deapina Ignatiadou 氏がマケドニアの埋葬用べッドのガラス象嵌装飾につい 
て報告した。

それぞれ意欲的な発表であったが, 特に Triantafyllidis 氏の発表は多くの発掘資料が 揃い，この分野が着々と進んでいる印象を持った。その他の発表については，専門分野 各氏の報告を待ちたい。

なお，学会による正式な大会報告は，これまで学会が発行する紀要に発表されてきた が，今回に関しては，Corning が発行する The Journal of Glass Studies に掲載される予 定である。 